Reprod. Nutr. Dévelop., 1980, 20 (1 B), 225-233

\title{
Hormones, metabolism and growth
}

par D. LISTER

ARC Meat Research Institute, Langford,

Bristol BS18 7DY U. K.

The literature of animal science, like that of other branches of science, grows inexorably, but it is surprising how many of the old problems are still with us. For example, during the last twenty or so years, a multitude of experiments has been undertaken to study the effects of breeding and feeding on the growth and efficiency of food use by animals. The evaluation of the results from each of these experiments requires knowledge of the interrelationships between bodily size, composition and metabolism. For more advanced considerations we ought to know the nature of the fundamental process involved. Yet, for information on the former we usually resort to the classical but rather limited investigations of forty or even a hundred years ago and we have only just started to contemplate the latter in relation to animal production. In this paper I have tried to remedy this by looking at some of the older issues in the light of more recent advances in animal physiology.

\section{Physiological games}

It is a common belief in animal production that it merely requires the shuffling of the appropriate genes to enable animals to produce lean meat in an increasingly rapid and efficient way. This is an untenable notion for the physiologist for comparative physiology is based on the premise that animals are more or less similar. So far as the efficiency of energy utilisation is concerned, for example, the reliance of mammals on the same physiological and biochemical processes for energy transduction must represent one ultimate limit. This is not to say, of course, that all animals are alike, but that they play similar physiological games for the purpose of ensuring continued survival and procreation using common ground rules. The skill in animal production is to recognise how individual animals or types play their particular games.

The ground rules.

The most obvious difference between animals is their size and it has always presented a major obstacle in comparative studies. Size is so important in relation to the form which animals adopt that «being the right size » is an important tenet in biology (D'Arcy Thompson, 1961). Ignorance of this has been a source of error in classical stories about giants. Gulliver, of Lilliput fame (Swift, 1977), was twelve times the stature of 
the Lilliputians but $12^{3}$ their weight. Swift thus recognised the arithmetical aspect of scaling which was known to Archimedes, but he did not see the physical implications. Haldane (1929) calculated that for the giants of Bunyan's Pilgrim's Progress to be sixty feet tall they must weigh $80-90$ tons. But he also realised that this weight is quite unsupportable by human bone which has increased its area of cross section by only $10^{2}$. So, if the giants Pope and Pagan were to be mobile their skeletons would quite clearly need to be modified. In reality the weight of the skeleton increases more than proportionally to an increase in body size to accommodate it. According to Kayser and Heusner (1964) the slope of the regression line is 1.13 .

The skeleton provides the body's framework and the system of levers to improve the efficiency of work done. Muscle exerts the necessary mechanical forces and increases in mass with skeletal bulk. Larger mammals tend, in general, to have a larger proportion of supporting tissue in their fat free bodies than do those which are several orders of magnitude smaller (Pitts and Bullard, 1968) but the phenomenon can be observed even within species (Pitts, 1963).

Fat is, of course, a major component of the body and apart from acting as an energy store and thermal blanket it plays a major role in determining form. Thus, in the wild, the largest mammals are notable for their fatness and also for the high proportion of fat contained in their subcutaneous depots (Lockyer, 1976). The smallest mammals on the other hand may have no more than 5 p. 100 of fat associated with their lean body mass and this is located almost exclusively within the abdominal cavity (Pitts and Bullard, 1968). A covering of fur or hair then provides the thermal insulation provided by the subcutaneous fat of the larger animals.

Even with a coat of fur and, in some, a small amount of fat, small mammals dissipate relatively more heat than larger ones. This has been attributed to their larger relative surface area which Rubner (1883) proposed as a common reference for metabolic rate. Kleiber (1932), however, after examining data from a wide range of species and size suggested that body weight expressed to the power 0.75 was more generally applicable than body weight 0.67 which follows from Rubner's findings. There is still debate about the size of the exponent but it has now been generally accepted (EAAP, 1965) that 0.75 is appropriate for interspecific comparisons.

\section{Physiological aspects of animal production}

It is one thing to show that there are several common features of metabolism and growth which, after suitable mathematical transformation, link mice and men and elephants, but it is quite another to suggest that all animals would be equally efficient in commercial animal production provided, that is, the enormous dietary and management problems were solved. Kleiber (1961), however, put the metabolic issues into perspective by demonstrating that irrespective of the difference in the size and metabolism of rabbits and cattle, the yield of meat to be obtained from a given quantity of food would be the same for both species. Whilst this notion is an over-simplification it identifies how well controlled are the relationships between feed consumption and production and the tight limits within which feed efficiency can be manipulated. Fowler (1976) took this argument further in his calculations of the improvements in energetic 
efficiency to be gained by modifying various characteristics of the growth of pigs and the marketing practice. Increasing the rate of lean deposition by 10 p. 100 or reducing fat deposition or maintenance by the same amount was no more efficient in terms of feed utilisation to $90 \mathrm{~kg}$ liveweight than reducing the slaughter weight to $81 \mathrm{~kg}$. Even greater improvements were possible if the pigs were slaughtered at $60 \mathrm{~kg}$ thereby taking advantage of the very favourable lean tissue feed conversion of pigs of that weight.

The general argument is further supported by examination of the proportional development of carcasses. Figure 1 shows, in triangular plots, how the carcase compositions of a wide selection of pigs, cattle and sheep change in consistent ways. Despite the enormously varied backgrounds of the animals there was little evidence of it in their carcase development. The proportionality of tissue development was maintained. Even fat, acknowledged to be the most variable component, did not seem to vary wholly independently of the lean body.
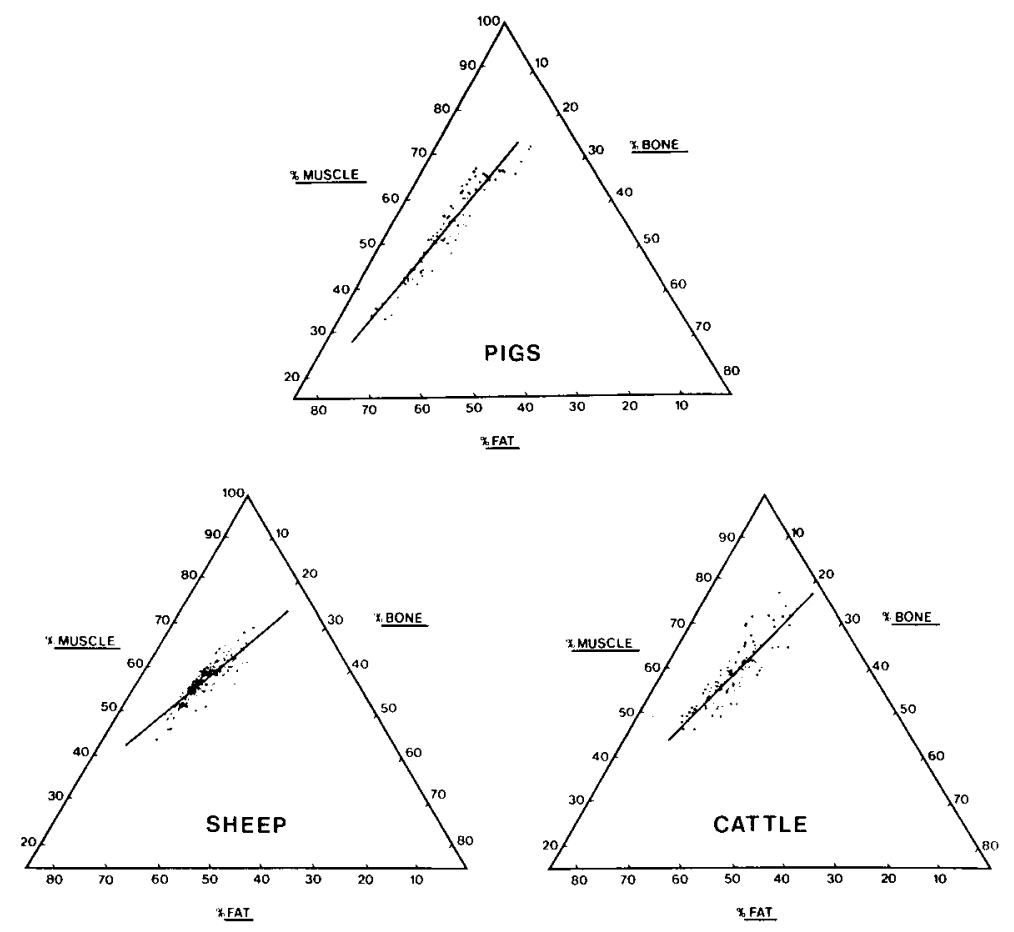

FIG. 1. - Triangular plof of the 3 major components of the carcasses (excluding head and feet) of (a), 99 pigs (weight range 10-300 kg), of 6 breeds and crosses, (b), 317 cattle (weight range 100-750 kg), of 42 breeds and crosses and (c), 165 sheep (weight range $5-55 \mathrm{~kg}$ ), of 20 breeds and crosses. For the fitting of regression lines, the points were referred to orthogonal axes where the vertical axis was $y=$ muscle $\cdot \frac{3}{2}$, i.e. muscle $\sin 60^{\circ}$, and the horizontal axis was $x=1-$ Fat $-\frac{\text { Muscle }}{2}$. For cattle, $y=0.139 \pm 0.0107$ (S.E.) $+0.848 \pm 0.0252 x$; for sheep. $y=0.079 \pm 0.0176+0.991 \pm 0.0403 x$, and for pigs, $y=0.011 \pm 0.0161+1.78 \pm 0.0413 x$. (Data from MRI records). 
The relative development of the different fat depots has long been recognised to complicate the analysis of the proportional development of the fat-free body especially when the effects of nutrition have been investigated (Wallace, 1948 ; Wilson, 1954, 1960). But Reid ef al. (1968) and Stant et al. (1968) showed that even when there were striking differences in the physical form of pigs of the same body weight, seemingly attributable to fat, they were not matched by differences in chemical composition. The subjective assessment of muscularity or fainess in animals is frequently confounded in the same way. "Conformation » and «finish » of beef cattle, for instance, are largely attributable to the amount and distribution of subcutaneous fat for there are no substantial differences between beef and dairy and even " unimproved 》 cattle in the relative amounts and distribution of muscle (Berg and Butterfield, 1976).

All of this goes to show that the overall growth of animals, as that of their constituent tissues, is a surprisingly predictable process. This is why, for a given species, the weight of the body alone provides the best single indicator of its composition. The relatively small residual variation in the composition of groups of animals of the same weight which arises through differences in nutrition and rates of tissue growth, especially fat, requires more sophisticated technology to analyse it. But there is no doubt that individual pigs, cattle and sheep differ in composition at their commercial slaughter weights. In view of what has gone before we can only conclude that this is primarily a function of the way feed is partitioned between muscle, fat and bone which, in turn depends on the timing of the individual tissue's development. All that can be achieved by breeding animals for meat production must be the synchronisation of the development of appropriate amounts of bodily tissues, which confers the optimal carcase composition and efficiency of feed utilisation, with the required slaughter weight.

As we saw earlier there are several routes by which such synchrony can be established. All are, however, variations in normal growth and achievable, presumably, by modification of similar if not the same fundamental mechanisms. The difficulty for the physiologist is to identify a common basis of reference amongst animals which will allow a pattern of controls to be identified. Clearly size, proportions of muscle, fat or bone, or metabolic rate are quite inadequate for this purpose and we must look elsewhere for an appropriate characteristic.

\section{A basis for physiological reference in animals}

Of all the many characteristics of tissue growth the siting of fat deposition appears to be the most variable. The extreme cases seem to be associated with bodily size. Whales, for example, are particularly noteworthy for the large amount of blubber their bodies contain, and the paucity of intra-abdominal fat (Lockyer, 1976). A mouse, on the other hand, may have very little fat in its body, but such as it has will be found associated with the internal organs and viscera. But amongst animals of the same species a similar, though smaller, trend can be observed. Lawes and Gilbert (1859), more than a hundred years ago, noticed how cattle differed in their partition of fat between internal and peripheral sites and this they considered to be a reflection of propensity to fatten. I took this notion and developed it as the Fat Partition Index (FPI) (Lister, 1976) which relates the amount of dissectible subcutaneous fat in the carcase to the sum of the 
weights of intermuscular, kidney knob and channel fat. In this way it is possible to rank not only different types of cattle, but pigs and sheep too (see fig. 2).

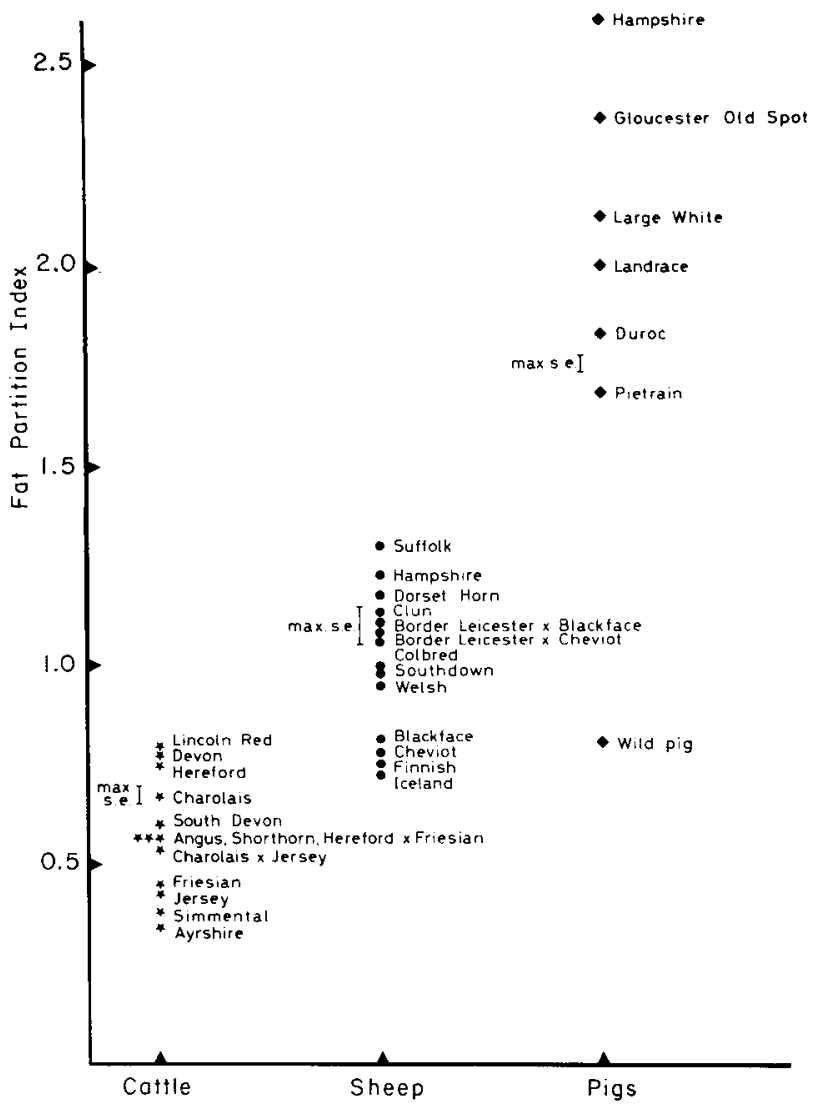

FIG. 2. - The Fat Partition Index (FPI) in farm animals (based on Lister, 1976).

It is apparent in figure 2 that samples from different breeds of the three species distribute themselves in quite characteristic ways. Moving from high to low values cattle fall generally into beef or dairy types ; sheep according to whether their natural environment is the lowland or upland, and pigs as to whether they are noted for being fat or lean. The higher values for pigs reflect the greater proportion of subcutaneous fat this species possesses. Although the FPI values are to some extent associated with the total fat contained in the carcase there is an effect attributable to genotype over and above this. A similar conclusion has been reached by Kempster ef al. (1976).

It is possible to identify many idiosyncratic characteristics amongst the animals represented in figure 2, but the common feature which emerges of interest to animal production is that the FPI provides an objective estimate of what is generally referred to as earliness or lateness of maturity. This is an important, though much abused, unifying concept in practical husbandry and the FPI as an indicator of this may provide at least a starting point in our search for a common basis of physiological reference. 


\section{Neuro-endocrine aspects of fat partition}

The FPI has been considered very generally in relation to nutrition and metabolism (Lister, 1976) and we need now to examine its relationship with the control of bodily growth such as is provided by nervous and hormonal mechanisms.

Although the term hormones was not coined until the early part of this century, some effects of the « ductless » glands had been noted long before this. Little progress was made in their investigation until methods for their analysis and synthesis became possible. Even now, however, we know far more about the actions of hormones in vitro than, say, of their role in disease, and considerably more than we do of their specific and combined effects in the control of variations in the patterns of normal growth and development. Thus any conclusions we may draw now about the latter, must be speculative.

There is no lack, nowadays, of suitable assays for all but a few of the major hormones can be routinely measured in blood. Investigations on human patients have enabled us to recognise ranges of normality for various hormones. But there are difficulties in knowing what the circulating levels of hormones indicate in physiological terms. Again, so far as man is concerned, longitudinal investigations of growth would take a lifetime of research and there is no legal opportunity to measure directly the compositions of the bodies of experimental subjects. Fortunately neither of these limitations apply to animal science though there are other difficulties of a clinical or methodological nature.

The pig has been a particularly useful experimental subject in this area of research because of its presentation of various syndromes which are associated with its growth, composition and behaviour. The Pietrain pig represents the classical extreme for the investigation of the physiology of these problems. It is typified by its low FPI, its lean carcase and the poor (pale, soft and exudative, PSE) quality of its meat. It is also highly sensitive to stressful stimuli. The discovery of an adverse reaction to certain drugs, notably halothane and suxamethonium, which is indistiguishable from that which may be seen after acute, severe stress, has presented experimenters with a unique model in which to investigate the hormonal and metabolic responses to stress.

Malignant Hyperthermia $(\mathrm{MH})$ as the syndrome is called develops in anaesthetised Pietrains when they are given the triggering drug. It is characterised by intense muscle stimulation, a developing acidosis and a rise in body temperature. The outcome is usually fatal (Lucke ef al., 1976). There is a dramatic rise in the concentrations of catecholamines, predominantly noradrenaline, in the plasma and the overall importance of the autonomic system and the adrenal medulla can be demonstrated by the prevention of the reaction by reserpinising or adrenalectomising and sympathetically blockading the animals (Lister ef al., 1974 ; Lucke ef al., 1978). $\alpha$-adrenergic blockade will also prevent a reaction developing after suxamethonium, and though $\beta$-blockade may modify some aspects of the syndrome, it will not allow recovery to occur (Lister ef al., 1976). It is considered that $\mathrm{MH}$ is part of a general stress syndrome which we believe is the result of a low threshold of sympathetic sensitivity. Muscular activify can, for instance, certainly prime a reaction in some pigs (Van den Hende ef al., 1976 ; Hall 
ef al., 1976) and drugs are not always necessary to cause a fatal response in particularly sensitive animals (Lister et al., 1976).

The relatively low incidence of this syndrome except in the Pietrain and some Landrace pigs raises questions of the validity and application of the model to pigs generally and certainly to farm species as a whole. The important consideration is, however, in the way that if brings together a number of quite separate experimental observations which have particular relevance to fat metabolism in animals.

Fat formation depends on the balance between lipolysis and lipogenesis in adipose tissue. Lipolysis is promoted in general in the presence of catecholamines, thyroid and growth hormones; lipogenesis, when the presence and activity of insulin is predominant (Siddle and Hales, 1975 ; Denton, 1975). The overriding control of all these appears to be in sympathetic nervous activity. Insulin is highly dependent upon it both to stimulate secretion ( $\beta$-adrenergic influence) and suppress it ( $\alpha$-adrenergic action) (Mayhew et al., 1969 ; Porte and Robertson, 1973). $\alpha$-adrenergic influence is indicated in the control of thyroid secretion rate (Melander et al., 1974) and in growth hormone secretion (Cryer and Daughaday, 1977).

If a mechanism, such as the threshold of sensitivity to autonomic or, specifically, sympathetic stimulation, represented a fundamental control system, then evidence of it should be available in other animals. Moreover if the FPI provides a unifying concept for farm animals, if not for animals generally, then all those with a low value for their kind should also show evidence of dependence on similar physiological characteristics to the Pietrain, and those with higher ones, physiological features of, say, the Large White or Gloucester Old Spot.

Gregory et al. (1977) and Wood ef al. (1977) have made detailed investigations of lipolysis and lipogenesis in Pietrains and Large Whites. There is clear evidence that fatty acids are more readily mobilised from and incorporated into the bodily tissues of Pietrains than Large Whites, and that this is associated with the poorer secreting ability and reduced sensitivity to insulin. Moreover Wood ef al. (1977) reported correlations of the order of 0.7-0.9 between the proportions of muscle and fat in the carcase and fasting insulin concentrations. Additional evidence for the lipolytic propensities of Pietrains is provided by their higher production of thyroid hormones and, by the recent demonstration, by means of a Valsalva-like manoevre, of their increases sympathetic sensitivity (Gregory and Lister, 1978 - in preparation).

Milk production in dairy cows might well be supposed to rely on their lipolytic potential and there is much evidence that it does. There is a marked tendency towards increased thyroid activity (Pipes et al., 1963) which is most marked during lactation (Sorensen, 1962). Joakimsen ef al. (1971) reported an important genetic association between the thyroxine degradation rate of bulls and the milk producing potential of their daughters. There is also a negative correlation with circulating insulin concentrations (Koprowski and Tucker, 1973) in lactating cattle and the levels of growth hormone, free fatty acids and $\beta$-hydroxybutyrate are raised (Bines and Hart, 1978).

We have only just begun to examine the hormonal status of sheep in relation to the FPl but there seems to be an association with thyroid activity, which increases in the order Hampshire, Southdown, Cheviot, Blackface which approximates to their ranking in the FPI (Lister and Lovell in preparation). 


\section{Conclusions}

Although there is a great need to identify particular neuro-endocrine relationships in the control of growth and development there are indications of the beginnings of an identifiable pattern amongst farm animals, which may relate to mammals generally. A growing predisposition towards fatness and a greater proportion of subcutaneous fat, so-called high FPI, appears to be attributable to a change in hormone balance away from a lipolytic to a lipogenic character in which the lipogenic and possibly protein anabolic (Cahill and Aoki, 1976) roles of insulin can emerge. There is no clear indication of how this is achieved, but there is supportive evidence that the autonomic nervous system might be important.

5e Réunion du groupe Développement I.N.R.A. Clermont-Ferrand/Theix, 17-18 mai 1979.

Acknowledgement. - I am grateful to Dr. H. J. H. MacFie for the statistical analysis of the data used in figure 1.

\section{References}

BERG R. T., BUTTERFIELD R. M., 1976. New concepts of cattle growth. Sydney Univ. Press, Sydney. BINES J. A., HART I. C., 1978. Milk or meat, 87-98. In Occasional publication, 1, Brit. Soc. Anim. Prod. CAHILL G. C., AOKI T. T., 1976. Protein-fat interactions, 221-232. In LISTER D., RHODES D. N., FOWLER V. R., FULLER M. F., Meat animals growth and productivity. Plenum Press, New York and London.

CRYER P. E., DAUGHADAY W. H., 1977. Adrenergic modulation of growth hormone secretion in acromegaly. J. clin. Endocr. Mefab., 44, 977-979.

DENTON R. M., 1975. Hormonal regulation of fatty acid synthesis in the activities of pyruvate dehydrogenase (EC1.2.4.1) and acetyl-CoA carboxylase (EC6.4.1.2). Proc. Nutr. Soc., 34, 217-224.

E.A.A.P., 1965. In BLAXTER K. L., Energy metabolism, 435. Acad. Press, London and New York.

POWLER V. R., 1976. Some aspects of energy utilization for the production of lean tissue in the pig. Proc. Nutr. Soc., 35, 75-79.

GREGORY N. G., LOVELL R. D. L., WOOD J. D., LISTER D., $1977 . \quad$ Insulin-secreting ability in Piétrain and Large-White pigs. J. agric. Sci. Camb., 89, 407-413.

HALDANE J. B. S., 1929. Possible worlds and other essays. Chatto and Windus. London.

HALL G. M., LUCKE J. N., LISTER D., 1976. Porcine malignant hyperthermia. IV. Neuromuscular blockade. Br. J. Anaesth., 48, 1135-1141.

JOAKIMSEN Ø., STEENBERG K., LIEN H., THEODORSEN L., 1971. Genetic relationship between thyroxine degradation and fat-connected milk yield in cattle. Acta agric. scand. 21, 121-124.

KAYSER C., HEUSNER A., 1964. Comparative study of energy metabolism in various animals. $J$. Physiol. Paris, 56, 489.

KEMPSTER A. J., CUTHBERTSON A., HARRINGTON G., 1976. Fat distribution in steer carcasses of different breeds and crosses. Anim. Prod., 23, 25-34.

KLEIBER M., 1932. Body size and metabolism. Hilgardia, 6, 315-353.

KLEIBER M., 1961. The fire or life. Wiley, New York,

KOPROWSKI J. A., TUCKER H. A., 1973. Bovine serum growth hormone, corticoids and insulin during lactation. Endocrinology, 93, 645-651.

LAWES J. B., GILBERT J. H., 1859. Experimental inquiry into the composition of some of the animals fed and slaughtered as human food. Phil. Trans. roy. Soc., 149, 493-678.

LISTER D., 1976. Effects of nutrition and genetics on the composition on the body. Proc. Nutr. Soc., 35, 351-356. 
LISTER D., HALL G. M., LUCKE J. N., 1974. Cafecholamines in suxamethonium-induced hyperthermia in Piétrain pigs. Br. J. Anaesth., 46, 803-804.

LISTER D., HALL G. M. and LUCKE J. N., 1976. Porcine malignant hyperthermia. III. Adrenergic blockade. Br. J. Anaesth., 48, 831-838.

LISTER D., LUCKE J. N., HALL G. M., 1976. Pale, soft exudative (PSE) meat, stress susceptibility and MHS in pigs : Endocrinological and general physiological aspects, 144-150. In Proceed. 3rd int. Conf. Production disease in farm animals. Pudoc, Wageningen.

LOCKYER C., 1976. Body weights of some species of large whales. J. Cons. int. Explor. Mer., 36, 259 273.

LUCKE J. N., DENNY H., HALL G. M., LOVELL R. D. L., LISTER D., 1978. Porcine malignant hyperthermia. VI. The effects of bilateral adrenalectomy and pre-treatment with bretylium on the halothane-induced response. Br. J. Anaesth., 50, 241-246.

LUCKE J. N., HALL G. M., LISTER D., 1976. Porcine malignant hyperthermia. I. Metabolic and physiological changes. Br. J. Anaesth., 48, 297-304.

MAYHEW D. A., WRIGHT P. H., ASHMORE J., 1969. Regulation of insulin secretion. Pharmac. Rev. 21, 183-212.

MELANDER A., ERICSON L. E., SUNDLER F., 1974. Sympathetic regulation of thyroid hormone secretion. Life Sci., 14, 237-246.

PIPES G. W., BAUMAN T. R., BROOKS J. R., COMFORT J. E., TURNER C. W., 1963. Effect of season, sex and breed on the thyroxine secretion rate of beef cattle and a comparison with dairy cattle. J. Anim. Sci., 22, 476-480.

PITTS G. C., 1963. Studies of gross body composition by direct dissection. Ann. N. Y. Acad. Sci. 110, 11-12.

PITTS G. C., BULLARD R. T., 1968. Some interspecific aspects of body composition in mammals, 4570. In Body composition in animals and man, Publ. 1598, Nat. Acad. Sci. Washington, D. C.

PORTE D. Jr., ROBERTSON R. P., 1973. Control of insulin secretion by catecholamines, stress and the sympathetic nervous system. Fed. Proc., 32, 1792-1796.

REID J. T., BENSADOUN A., BULL L. S., BURTON J. H., GLEESON P. A., HAN I. K., JOO Y. D., JOHNSON D. E., MCMANUS W. R., PALADINES O. L., STROUD J. W., TYRELL H. F., VAN NIEKERK B. D. H., WELLINGTONG. W., 1968. Some pecularities in the body composition of animals, 19-44. In Body composition in onimals and man, Publ. 1598, Nat. Acad. Sci., Washington, D. C.

RUBNER M., 1883. Ueber den Einfluss der Korpergrosse auf Stoff und Kraftwechsel. Z. Biol., $19,535$. SIDDLE K., HALES C. N., 1975. Hormonal control of adipose tissue lipolysis. Proc. Nutr. Soc., 34, $233-$ 240.

SORENSEN P. H., 1962. Studies of thyroid function in cattle and pigs, 455-466. In Use of radioisotopes in animal biology and the medical sciences. Acad. Press, London and New York.

STANT E. G., MARTIN T. G., JUDGE M. D., HARRINGTON R. B., 1968. Physical separation and chemical analysis of the porcine carcass at 23,46, 68 and $91 \mathrm{~kg}$ liveweight. J. Anim. Sci., $27,636$.

SWIFT J., 1977. Gulliver's Travals. Pan Books, London.

THOMPSON D'A., 1961. On growth and form. Cambridge Univ. Press, London.

VAN DEN HENDE C., LISTER D., MUYLLE E., OOMS L., OYAERT W., 1976. Malignant hyperthermia in Belgian Landrace pigs rested or exercised before exposure to halothane. $\mathrm{Br}$. J. Anaesth., 48, 821-829.

WALLACE L. R., 1948. The growth of lambs before and after birth in relation to the level of nutrition. J. agric. Sci. Camb., 38, 367-401.

WILSON P. N., 1954. Growth analysis of the domestic fowl. III. J. agric. Sci. Camb., 45, $110-124$.

WILSON P. N., 1960. The effect of plane of nutrition on the growth and development of the East African dwarf goat. III. J. agric. Sci. Camb., 54, 105-134.

WOOD J. D., GREGORY N. G., HALL G. M., LISTER D., 1977. Fat mobilization in Piétrain and Large White pigs. Br. J. Nutr., 37, 167-186. 